CZASOPISMO INŻYNIERII LADOWEJ, ŚRODOWISKA I ARCHITEKTURY JOURNAL OF CIVIL ENGINEERING, ENVIRONMENT AND ARCHITECTURE

JCEEA, t. XXXII, z. 62 (3/I/15), lipiec-wrzesień 2015, s. 153-168

Ryszarda IWANEJKO ${ }^{1}$

\title{
NOWA ANALITYCZNA METODA DO WYZNACZANIA ŚREDNIEJ ILOŚCI NIEODPROWADZONYCH ŚCIEKÓW DLA SYSTEMÓW KANALIZACJI PODCIŚNIENIOWEJ I GRAWITACYJNEJ
}

\begin{abstract}
Zadaniem systemu kanalizacyjnego jest odprowadzanie przewidzianej ilości ścieków z danego terenu. Systemy kanalizacyjne należą do krytycznej infrastruktury miejskiej, powinny więc charakteryzować się wysoką niezawodnością działania. W przypadku awarii tych systemów ścieki nie będą odprowadzone i mogą powodować zanieczyszczenie gruntu i powierzchni terenu a czasami zanieczyszczenie wód podziemnych, zalewanie obiektów podziemnej infrastruktury miejskiej, podtapianie fundamentów budynków czy też katastrofy kanalizacyjne. Skutki awarii systemów kanalizacyjnych dotykają więc nie tylko mieszkańców skanalizowanych terenów lecz przede wszystkim środowiska naturalnego. Działające współcześnie systemy kanalizacyjne składają się z elementów i obiektów, których okres eksploatacji przekracza wiele dziesięcioleci, a stan techniczny często nie jest zadowalający. Dlatego też przypadki niesprawności kanalizacji są dość częste. Wygodnym podstawowym wskaźnikiem charakteryzującym niezawodność sieci kanalizacyjnych jest średnia ilość nieodprowadzonych ścieków EN. Znane i stosowane dotychczas metody wyznaczania EN nie spełniają wszystkich kryteriów przydatności. Albo są zbyt pracochłonne i trudne w praktycznych zastosowaniach, albo po ich uproszczeniu nie pozwalają na ocenę błędu metody. W artykule przedstawiono oryginalną metodę, tzw. metodę kumulacji niedoborów (MKN) pozwalającą na wyznaczenie spodziewanej ilości ścieków nieodprowadzonych z danego terenu. Jest metodą prostą, intuicyjnie zrozumiałą, dokładną i o niewielkiej pracochłonności. Opracowanie metody wymagało innego, nietradycyjnego podejścia do wyznaczenia średniego niedoboru. Metodę można stosować dla systemów kanalizacji grawitacyjnej, podciśnieniowej i mieszanej bez ograniczenia liczby elementów budujących system kanalizacyjny.
\end{abstract}

Słowa kluczowe: niezawodność, uszkodzenie, kanalizacja, ścieki

\footnotetext{
${ }^{1}$ Ryszarda Iwanejko, Politechnika Krakowska, ul. Warszawska 24, 31-155 Kraków, tel. 12628 2552, riw@vistula.wis.pk.edu.pl
} 


\section{Wprowadzenie}

Systemy kanalizacyjne (SK), obok systemów wodociągowych, grzewczych i ciepłowniczych są strategicznymi systemami infrastruktury miejskiej. Zadaniem SK jest zebranie $\mathrm{z}$ danego obszaru powstających tam ścieków (bytowogospodarczych, przemysłowych, opadowych) i odprowadzenie ich do odbiornika. To zadanie SK muszą bardzo wypełniać $\mathrm{z}$ wysokim prawdopodobieństwem w sposób ciągły, a wymagania wobec nich mogą zostać złagodzone jedynie w sytuacjach wyjątkowych (np. ekstremalne warunki pogodowe, stan wojenny). Niewypełnianie zadań przez SK wskutek awarii może powodować duże straty materialne, społeczne i środowiskowe. Przyczyny awarii sieci kanalizacyjnych mogą mieć związek z jego projektowaniem (np. przyjęcie niewłaściwych obciążeń statycznych, dynamicznych, hydraulicznych, konstrukcyjnych), wykonawstwem (np. zastosowanie nieodpowiednich materiałów, niedbałe wykonawstwo) i eksploatacją (np. brak przeglądów, konserwacji, procesy starzeniowe) [4]. Skutkiem poważnych uszkodzeń mogą być: (1) eksfiltracja ścieków do gruntu powodująca zanieczyszczanie gruntu czy wód podziemnych, (2) infiltracja wód przypadkowych powodująca przeciążenie hydrauliczne sieci kanalizacyjnej i oczyszczalni ścieków nadmiernie rozcieńczonymi ściekami, co źle wpływa na efektywność oczyszczali, (3) zalewanie terenów i obiektów podziemnej infrastruktury technicznej, (4) katastrofy kanalizacyjne [7]. Systemy kanalizacyjne są rozległe, złożone o strukturze drzewiastej, są zbudowane z różnych elementów, są dynamiczne, charakteryzują się znaczną zmiennością ilości odprowadzanych ścieków, podlegają losowym obciążeniom [4]. Ocena niezawodności SK jest więc trudna. Przez niezawodność funkcjonowania sieci kanalizacyjnej SK rozumie się jej zdolność do ciągłego i prawidłowego zbierania i odprowadzania nominalnej ilości ścieków (tj. takiej, na jaką sieć została zaprojektowana) w dowolnej chwili w danych warunkach eksploatacyjnych. Jedną z miar niezawodności SK jest EN średnia ilość ścieków nieodprowadzonych z danego obszaru. Przez analogię do systemów wodociągowych jest też czasem krótko nazywana średnim niedoborem. Jest to w pewnym sensie miara podstawowa, gdyż na jej podstawie można określić inne miary np. uogólniony wskaźnik niezawodności Ku $[4,6,7]$ czy ryzyko [4]. Metoda wyznaczania i wykorzystania średniego niedoboru EN po raz pierwszy została przedstawiona w 1984 roku przez prof. Artura Wieczystego, twórcę tzw. Krakowskiej Szkoły Niezawodności [7]. Od tego czasu miary EN i Ku były wykorzystywane w kraju do charakteryzowania obiektów wodociągowych i kanalizacyjnych. Innymi miarami mogą być uszkadzalność $\lambda_{0}$, średni czas niesprawności Tn czy stacjonarny wskaźnik gotowości K. Do wyznaczania miar niezawodności SK można stosować metody bezpośrednie tj. statystyczne, w których nie wnika się $w$ strukturę SK oraz metody pośrednie tj. metody analizy strukturalnej, których podstawą jest uwzględnienie struktury systemu, typów elementów, powiązań miedzy nimi i rodzajów rezerw tkwiących w systemie [4]. Spośród metod pośrednich do wyznaczania EN dotychczas stosowano metody 
przeglądu [4] lub metodę dekompozycji i ekwiwalentowania [5]. Jednak te metody nie spełniają wszystkich oczekiwań. Albo są bardzo pracochłonne, albo dają wyniki przybliżone. Dlatego podjęto próbę opracowania nowej metody tzw. metody kumulowania niedoborów (MKN). Metoda kumulowania niedoborów polega na stopniowym uwzględnianiu niedoborów, czyli skutków niesprawności wszystkich elementów (lub grup elementów) systemu. W rezultacie, podobnie jak w metodzie przeglądu zupełnego, lecz przy znikomej pracochłonności, uzyskuje się dokładną wartość średniego niedoboru EN. Różnicą obu metod jest sposób wyznaczania niedoborów.

W metodach przeglądu dla wyznaczonych stanów elementarnych systemu określa się prawdopodobieństwa ich zajścia oraz niedobory. Średnią ilość nieodprowadzonych ścieków wyznacza się jako $\mathrm{EN}=\sum_{\mathrm{z}} \mathrm{Nz} \cdot \mathrm{Pz}$, gdzie z - numer stanu elementarnego systemu, Pz- prawdopodobieństwo jego zajścia, Nz - niedobór w z tym stanie systemu. Wyróżnia się dwie metody przeglądu: metodę przeglądu zupełnego (MPZ) i metodę przeglądu częściowego (MPCz). W MPZ wypisuje się explicite wszystkie stany elementarne systemu, dla których $\mathrm{k}$ liczba równocześnie uszkodzonych elementów systemu przyjmuje kolejno wartości $\mathrm{k}=0,1,2, \ldots \mathrm{n}$ ( $\mathrm{n}-$ liczba elementów systemu). Pracochłonność metody dla rzeczywistych systemów o znacznej liczbie elementów (n duże) może być ogromna, gdyż jest związana $\mathrm{z}$ koniecznością wyznaczenia $\mathrm{I}(\mathrm{MPZ})=2^{\mathrm{n}}$ stanów elementarnych systemu. Innym, chętnie stosowanym, rozwiązaniem jest metoda przeglądu częściowego (MPCz), uwzględniająca jedynie najbardziej prawdopodobne stany sytemu. W praktyce $\mathrm{MPCz}$ ograniczano do $\mathrm{k} \leq 2$, co oznacza że analizowano $\mathrm{I}(\mathrm{MPCz})=\left(\begin{array}{l}\mathrm{n} \\ 0\end{array}\right)+\left(\begin{array}{l}\mathrm{n} \\ 1\end{array}\right)+\left(\begin{array}{l}\mathrm{n} \\ 2\end{array}\right)$ stanów systemu. Na ogół nie szacuje przy tym dokładności uzyskanego wyniku EN(MPCz), uważając, że wobec konieczności ograniczenia pracochłonności obliczeń i stosunkowo wysokich wartościach niezawodności wszystkich elementów uzyskany wynik jest wystarczająco dokładny.

W innej nowej metodzie tzw. metodzie dekompozycji i ekwiwalentowania [5] dokonuje się stopniowego wydzielania fragmentów sieci w kształcie litery „Y” i ich zamiany na równoważny fikcyjny kanał. Dla każdego fragmentu „Y” tj. dla trzech odcinków, uwzględnia się możliwość zajścia co najwyżej jednego uszkodzenia. Takie uproszczenie może być przyczyną uzyskania niedokładnych wyników, co trudno ocenić, gdyż w metodzie tej nie szacuje się możliwego błędu.

W podstawowej wersji metody kumulacji niedoborów (MKN) podejście jest inne. Kolejno dla wszystkich elementów systemu $(\mathrm{i}=1,2, \ldots \mathrm{n})$ wyznacza się tzw. średnie niedobory skumulowane. Wyznaczony na i-tym etapie ( $\mathrm{tj}$. dla i-tego elementu) średni niedobór skumulowany oznaczany jako ENs(i) uwzględnia niedobory generowane przez elementy o numerach $\mathrm{j}=1,2$,...i $\mathrm{Na}$ ostatnim etapie uzyskuje się ENs(n), którego wartość jest równa średniemu niedoborowi EN(MPZ) uzyskanemu za pomocą MPZ. 
W artykule przedstawiono zasady stosowania MKN dla systemów kanalizacji sanitarnej podciśnieniowej (SKP) i grawitacyjnej (SKG). W kanalizacji podciśnieniowej przepływ ścieków jest wymuszany poprzez wytwarzanie podciśnienia i zasysanie ścieków. W kanalizacji grawitacyjnej ścieki przepływają pod wpływem siły ciężkości. W dalszej części, w obu przypadkach, zakłada się, że elementy są dwustanowe (tzn. w dowolnej chwili czasu element albo jest zdatny albo jest niezdatny). Prawdopodobieństwo zdatności każdego i-tego elementu jest wyrażone wartością stacjonarnego wskaźnika gotowości i jest równe Ki. Przyjmuje się, że aby uznać system za sprawny, to musi on spełniać ostre kryterium sprawności, tzn. Qw=Qn , gdzie Qw - wymagana ilość odprowadzonych ścieków z danego obszaru, Qn - nominalna ilość ścieków, którą należy odprowadzić. Inaczej mówiąc: SK uznaje się za sprawny, jeśli z danego obszaru odprowadzi wszystkie ścieki. Przy takim kryterium, niesprawność dowolnego elementu powoduje niesprawność systemu. Zakłada się również, że elementy uszkadzają się niezależnie, jednak skutki uszkodzeń elementów zależą od typu elementu. Przyjmuje się, że w systemie mogą być dwa typy elementów: krytyczne i zwykłe. Elementy krytyczne to takie, których niesprawność, bez względu na stany pozostałych elementów, powoduje wyłączenie z pracy innych (podrzędnych) elementów i powstanie sumarycznego dużego niedoboru. Elementy zwykłe to takie, których niesprawność nie powoduje przerwy w pracy innych elementów.

\section{Metoda dla kanalizacji podciśnieniowej}

Idę metody MKN dla najprostszego przypadku kanalizacji podciśnieniowej przedstawiono poniżej. Przyjęto, że system $\mathrm{S}$ składa się $\mathrm{z} n=3$ elementów o numerach $\mathrm{i}=1,2,3$. Ilość ścieków, która musi być odprowadzone przez każdy i-ty element (przez analogię do systemów wodociągowych używane też będzie określenie: wydajność elementu) wynosi Qi. Niesprawność dowolnego i-tego elementu systemu oznacza powstanie niedoboru $\mathrm{Ni}=\mathrm{Qi}$. Elementy 1 i 2 nie są elementami krytycznymi tzn. N1=Q1<Qn oraz N2=Q2<Qn. Mogą więc być odpowiednikami obiektów domowych podłączonych do kanalizacji podciśnieniowej. Jako obiekt domowy rozumie się tutaj podłączenie kanalizacyjne, które poprzez studzienkę zbiorczą z zawodem opróżniającym jest połączone z siecią podciśnieniową. Element 3 jest elementem krytycznym i może być odpowiednikiem kolektora podciśnieniowego. Wówczas zachodzi N3=Q3=Q1+Q2=Qn.

Procedurę wyznaczania niedoboru dla całego SKP rozpoczyna się od pierwszego elementu systemu ( $\mathrm{i}=1)$. Jego średni niedobór, będący równocześnie niedoborem skumulowanym ENs(1) wynosi (tab.1).

$$
\mathrm{EN}(1)=\mathrm{ENs}(1)=0 \cdot \mathrm{K} 1+\mathrm{Q} 1 \cdot(1-\mathrm{K} 1)=\mathrm{Q} 1 \cdot(1-\mathrm{K} 1)
$$


Tabela 1. Wyznaczanie średniego niedoboru dla pierwszego elementu systemu

Table 1. Determination of an average shortage for the first element of the system

\begin{tabular}{|c|c|c|c|c|}
\hline $\begin{array}{c}\text { Ele- } \\
\text { ment }\end{array}$ & $\begin{array}{c}\text { Stan } \\
\text { ele- } \\
\text { mentu } \\
\mathbf{1}\end{array}$ & $\begin{array}{c}\text { Niedobór wynikają- } \\
\text { cy z niesprawności } \\
\text { elementu 1 }\end{array}$ & $\begin{array}{c}\text { Prawdopodo- } \\
\text { bieństwo }\end{array}$ & $\begin{array}{c}\text { Średni niedobór EN1= } \\
\text { ENs(1) }\end{array}$ \\
\hline \multirow{2}{*}{1} & + & 0 & $\mathrm{~K} 1$ & \multirow{2}{*}{$E N s(1)=Q 1 \cdot(1-K 1$} \\
\cline { 2 - 4 } & - & $\mathrm{N} 1=\mathrm{Q} 1$ & $1-\mathrm{K} 1$ & \\
\hline
\end{tabular}

Dołóżmy do tego pierwszego elementu drugi element (i=2) i zastosujmy MPZ (tab.2).

Tabela 2. Wyznaczanie średniego niedoboru za pomocą MPZ dla elementów 1 i 2

Table 2. Determination of an average shortage using MPZ for elements 1 and 2

\begin{tabular}{|c|c|c|c|c|}
\hline \multirow{2}{*}{$\begin{array}{c}\text { Stan } \\
\text { sys- } \\
\text { temu }\end{array}$} & $\mathbf{1}$ & $\mathbf{2}$ & Prawdopodobieństwo & Niedobór \\
\cline { 2 - 3 } & + & + & $\mathrm{K} 1 \cdot \mathrm{K} 2$ & 0 \\
\hline 1 & + & - & $\mathrm{K} 1 \cdot(1-\mathrm{K} 2)$ & $\mathrm{Q} 2$ \\
\hline 2 & - & + & $(1-\mathrm{K} 1) \cdot \mathrm{K} 2$ & $\mathrm{Q} 1$ \\
\hline 3 & - & - & $(1-\mathrm{K} 1) \cdot(1-\mathrm{K} 2)$ & $\mathrm{Q} 1+\mathrm{Q} 2$ \\
\hline 4 & & &
\end{tabular}

Wówczas średni niedobór skumulowany (tj. niedobór wyznaczony dla dwóch pierwszych elementów systemu) wynosi:

$$
\begin{aligned}
& \mathrm{EN}(\mathrm{MPZ} ; \mathrm{n}=2)=\mathrm{Q} 1 \cdot(1-\mathrm{K} 1) \cdot \mathrm{K} 2+\mathrm{Q} 2 \cdot \mathrm{K} 1 \cdot(1-\mathrm{K} 2)+ \\
& (\mathrm{Q} 1+\mathrm{Q} 2) \cdot(1-\mathrm{K} 1) \cdot(1-\mathrm{K} 2)
\end{aligned}
$$

Taki sam wynik uzyskamy za pomocą MKN kontynuując pierwszą tabelę uzupełnioną jednakże o dodatkową kolumnę (tab.3). Tutaj, niezależnie od stanu niezawodnościowego elementu 2, należy dodać średni niedobór skumulowany ENs(1) związany z elementem pierwszym.

Przy stosowaniu MPZ i MKN uzyskujemy tę samą wartość. Wystarczy bowiem przekształcić uzyskane wartości i w obu przypadkach uzyskujemy

$$
\begin{aligned}
& \mathrm{EN}(\mathrm{MPZ} ; \mathrm{n}=2)=\mathrm{ENs}(2)= \\
& =\mathrm{Q} 1+\mathrm{Q} 2-\mathrm{Q} 1 \cdot \mathrm{K} 1-\mathrm{Q} 2 \cdot \mathrm{K} 2=\mathrm{Q} 1 \cdot(1-\mathrm{K} 1)+\mathrm{Q} 2 \cdot(1-\mathrm{K} 2)= \\
& =\mathrm{EN}(1)+\mathrm{EN}(2)=\mathrm{Q} 1 \cdot(1-\mathrm{K} 1)+\mathrm{Q} 2 \cdot(1-\mathrm{K} 2)
\end{aligned}
$$


Tabela 3. Wyznaczanie średniego niedoboru skumulowanego dla drugiego elementu systemu

Table 3. Determination of an average cumulated shortage for the second element of the system

\begin{tabular}{|c|c|c|c|c|c|}
\hline \multirow[b]{2}{*}{ 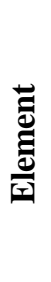 } & \multirow{2}{*}{ 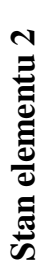 } & \multicolumn{2}{|c|}{ Niedobór } & \multirow[b]{2}{*}{$\begin{array}{l}\text { Prawdopo- } \\
\text { dobieństwo }\end{array}$} & \multirow[b]{2}{*}{$\begin{array}{c}\text { Średni niedobór skumulo- } \\
\text { wany } \operatorname{ENs}(2)\end{array}$} \\
\hline & & $\begin{array}{l}\text { wynikają- } \\
\text { cy z nie- } \\
\text { sprawno- } \\
\text { ści elemen- } \\
\quad \text { tu } 2\end{array}$ & $\begin{array}{l}\text { skumu- } \\
\text { lowany } \\
\text { dla } \mathbf{i = 1}\end{array}$ & & \\
\hline \multirow[b]{2}{*}{2} & + & 0 & ENs(1) & $\mathrm{K} 2$ & \multirow{2}{*}{$\begin{array}{l}\mathrm{ENs}(1) \cdot \mathrm{K} 2+ \\
{[\mathrm{Q} 2+\mathrm{ENs}(1)] \cdot(1-\mathrm{K} 2)}\end{array}$} \\
\hline & - & $\mathrm{N} 2=\mathrm{Q} 2$ & ENs(1) & $1-\mathrm{K} 2$ & \\
\hline
\end{tabular}

Jak widać, średni niedobór jest równy sumie średnich niedoborów zwykłych elementów systemu. Nie jest przy tym istotna kolejność uwzględniania elementów, co więcej: dla systemu o większej liczbie (m) elementów zwykłych zamiast stopniowego wyznaczania średnich niedoborów skumulowanych ENs(i) można od razu wyznaczyć średni niedobór dla wszystkich m uwzględnianych zwykłych elementów systemu jako:

$$
\mathrm{EN}(\mathrm{MPZ} ; \mathrm{m})=\mathrm{ENs}(\mathrm{m})=\sum_{\mathrm{i}=1}^{\mathrm{m}} \mathrm{EN}(\mathrm{i})=\sum_{\mathrm{i}=1}^{\mathrm{m}} \mathrm{Qi} \cdot(1-\mathrm{Ki})
$$

Weźmy teraz pod uwagę element trzeci ( $\mathrm{i}=3$ ), który jest elementem krytycznym. Dla tego elementu zachodzi Q3=Q1+Q2=Qn=Qw. Podobnie jak poprzednio niedobór skumulowany ENs(3) wyznacza się za pomocą tabeli (tab.4). Jednak wyznaczanie średniego niedoboru skumulowanego dla elementu krytycznego (i=3) różni się od przedstawionego powyżej wyznaczania średniego niedoboru skumulowanego dla elementów zwykłych $(\mathrm{i}=1,2)$. Tutaj, w przypadku niesprawności elementu krytycznego, do niedoboru N3 nie dodaje się skumulowanego z poprzedniego poziomu, lecz należy przyjąć niedobór równy $\mathrm{N} 3=\mathrm{Q} 3$.

Stąd:

$\mathrm{ENs}(3)=\mathrm{ENs}(2) \cdot \mathrm{K} 3+\mathrm{Q} 3 \cdot(1-\mathrm{K} 3)$

Wykorzystując (3) uzyskujemy więc

$$
\operatorname{ENs}(3)=[\mathrm{EN}(1)+\mathrm{EN}(2)] \cdot \mathrm{K} 3+\mathrm{Q} 3 \cdot(1-\mathrm{K} 3)
$$

Po dokonaniu szeregu przekształceń mamy

$$
\operatorname{ENs}(3)=\mathrm{Q} 1 \cdot(1-\mathrm{K} 1 \cdot \mathrm{K} 3)+\mathrm{Q} 2 \cdot(1-\mathrm{K} 2 \cdot \mathrm{K} 3))
$$


Tabela 4. Wyznaczanie średniego niedoboru skumulowanego dla trzeciego krytycznego elementu systemu

Table 4. Determination of an average cumulated shortage for the third critical element of the system

\begin{tabular}{|c|c|c|c|c|c|}
\hline \multirow{2}{*}{ 衺 } & \multirow{2}{*}{ 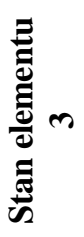 } & \multicolumn{2}{|c|}{ Niedobór } & \multirow[b]{2}{*}{$\begin{array}{l}\text { Prawdopo- } \\
\text { dobieństwo }\end{array}$} & \multirow[b]{2}{*}{$\begin{array}{c}\text { Średni niedobór skumulo- } \\
\text { wany } \operatorname{ENs}(3)\end{array}$} \\
\hline & & $\begin{array}{l}\text { wynikający z } \\
\text { niesprawności } \\
\text { elementu } 3\end{array}$ & $\begin{array}{l}\text { skumu- } \\
\text { lowany } \\
\text { dla } i=2\end{array}$ & & \\
\hline \multirow{2}{*}{3} & + & 0 & $\mathrm{ENs}(2)$ & K3 & \multirow{2}{*}{$\begin{array}{l}\mathrm{ENs}(2) \cdot \mathrm{K} 3+ \\
\mathrm{Q} 3 \cdot(1-\mathrm{K} 3)\end{array}$} \\
\hline & - & $\mathrm{N} 3=\mathrm{Q} 3=\mathrm{Qn}$ & $\mathrm{ENs}(2)$ & $1-\mathrm{K} 3$ & \\
\hline
\end{tabular}

Jeśli dla $\mathrm{n}=3$ elementów zastosujemy MPZ, to po dokonaniu szeregu przekształceń mamy EN $(\mathrm{MPZ} ; \mathrm{n}=3)=\mathrm{Q} 1 \cdot(1-\mathrm{K} 1 \cdot \mathrm{K} 3)+\mathrm{Q} 2 \cdot(1-\mathrm{K} 2 \cdot \mathrm{K} 3))$.

Stąd wniosek, że oba niedobory: tj. niedobór skumulowany ENs(3) i niedobór EN(MPZ;n=3). wyznaczony w sposób tradycyjny za pomocą MPZ są równe. Jak widać stosowanie MKN dla analizowanego przypadku jest intuicyjnie bardzo proste, o niewielkiej pracochłonności a uzyskany wynik średniego niedoboru EN jest dokładny.

Przeanalizujmy teraz bardziej złożony przypadek, gdy system składa się $\mathrm{z}(\mathrm{J}+1)$ grup elementów jednorodnych. Wszystkie grupy z wyjątkiem ostatniej zawierają elementy zwykłe (np. obiekty domowe), natomiast ostatnia grupa zawiera jedynie obiekty krytyczne (np. kolektor podciśnieniowy KP, stację próżniową SP). Liczność każdej grupy Gj wynosi nj. Wydajność dowolnego elementu w j-tej grupie wynosi $\mathrm{Qj}$, generowany niedobór $\mathrm{Nj}=\mathrm{Qj}$, a jego niezawodność $\mathrm{Kj}$. Przy wyznaczania średniego niedoboru systemu zastosujemy MKN w analogiczny sposób jak poprzednio zastępując jednakże pojedyncze elementy grupami elementów. Jest oczywiste, że grupy elementów nie są obiektami dwustanowymi lecz są wielostanowe. W sytuacji, gdy elementy zwykłe uszkadzają się i działają w sposób niezależny, to średni niedobór generowany przez j-tą grupę zwykłych $(\mathrm{j}=1, . . \mathrm{J})$ można wyznaczyć $\mathrm{z}$ wykorzystaniem wzoru Bernoulliego jako

$$
E N(G j)=\sum_{k=1}^{n j}\left(\begin{array}{l}
n j \\
k
\end{array}\right) \cdot(n j \cdot Q j) \cdot K j^{n j-k} \cdot(1-K j)^{n j}
$$

gdzie j - numer grupy, nj - liczebność grupy $\mathrm{Gj}, \mathrm{k}$ - liczba elementów grupy równocześnie uszkodzonych. Ze względu na własność addytywności wartości oczekiwanej dowolnej zmiennej losowej, ten sam średni niedobór grupy elementów zwykłych Gj można wyznaczyć o wiele łatwiej, gdyż na podstawie (4) jest on równy sumie średnich niedoborów elementów danej grupy, czyli 


$$
\mathrm{EN}(\mathrm{Gj})=\sum_{\mathrm{i}=1}^{\mathrm{nj}} \mathrm{Qj} \cdot\left(1-\mathrm{K}_{\mathrm{j}}\right)=\mathrm{nj} \cdot \mathrm{Qj} \cdot\left(1-\mathrm{K}_{\mathrm{j}}\right)
$$

Po wyznaczeniu średniego niedoboru dla wszystkich grup elementów zwykłych $\mathrm{EN}(\mathrm{G} 1), \ldots \mathrm{EN}(\mathrm{GJ})$, należy wyznaczyć średni niedobór skumulowany dla tych grup. Podobnie jak poprzednio, ze względu na własność addytywności, również na podstawie (4) zachodzi

$$
\operatorname{ENs}(G J)=E N(G 1, G 2, . . G J)=\sum_{j=1}^{J} \quad E N(G j)=\sum_{j=1}^{J} n j \cdot Q j \cdot\left(1-K_{j}\right)
$$

Kolejnym krokiem jest wyznaczenie średniego niedoboru dla całego systemu. Analogicznie jak wcześniej (wzór (5)) zastosujemy wzór na średnią ważoną. Ponieważ niedobór generowany przez grupę elementów krytycznych wynosi $\mathrm{N}(\mathrm{G}(\mathrm{J}+1))=\mathrm{Qn}$, to

$$
\mathrm{EN}(\mathrm{S})=\mathrm{ENs}(\mathrm{GJ}) \cdot \mathrm{K}(\mathrm{G}(\mathrm{J}+1))+\mathrm{Qn} \cdot[1-\mathrm{K}(\mathrm{G}(\mathrm{J}+1)]
$$

gdzie $\mathrm{K}(\mathrm{G}(\mathrm{J}+1))$ to niezawodność (J+1)-szej grupy elementów krytycznych, która wynosi $\mathrm{K}(\mathrm{G}(\mathrm{J}+1))=\mathrm{K}_{\mathrm{J}+1}^{\mathrm{n}(\mathrm{J}+1)}$. Jak widać, dla systemu kanalizacji podciśnieniowej, złożonego praktycznie z nieograniczonej liczby zwykłych obiektów domowych o dowolnych wydajnościach i niezawodnościach oraz z jednego kolektora podciśnieniowego, stacji próżniowej (dwa elementy krytyczne) stosowanie metody kumulacji niedoborów jest bardzo proste, a uzyskany wynik jest dokładny.

Przedstawione powyżej zasady stosowania MKN umożliwiają wyznaczanie średniego niedoboru systemu EN(SK) dla dowolnych systemów kanalizacji podciśnieniowej. Jak widać, poprzez zastosowanie wzoru (10) dla różnych elementów zwykłych, tam gdzie jest to możliwe, stosowanie metody znacznie uproszcza się. Praktyczny sposób prowadzenia obliczeń dla bardziej skomplikowanego systemu przedstawiono poniżej.

\section{$\underline{\text { Przykład }}$}

System kanalizacji podciśnieniowej (SKP) składa się z dwóch kolektorów podciśnieniowych, jednej stacji próżniowej oraz obiektów domowych zlokalizowanych wzdłuż dwóch dróg (rys.1). Do kolektora pierwszego $\left(\mathrm{KP}_{\mathrm{A}}\right)$ jest podłączonych $\mathrm{n}_{\mathrm{A}}=8$ domów, a do kolektora drugiego $\left(\mathrm{KP}_{\mathrm{B}}\right)$ jest podłączonych $\mathrm{n}_{\mathrm{B}}=5$ domów. Wydajności i wskaźniki niezawodności obiektów systemu zestawiono w tabeli 5 . 


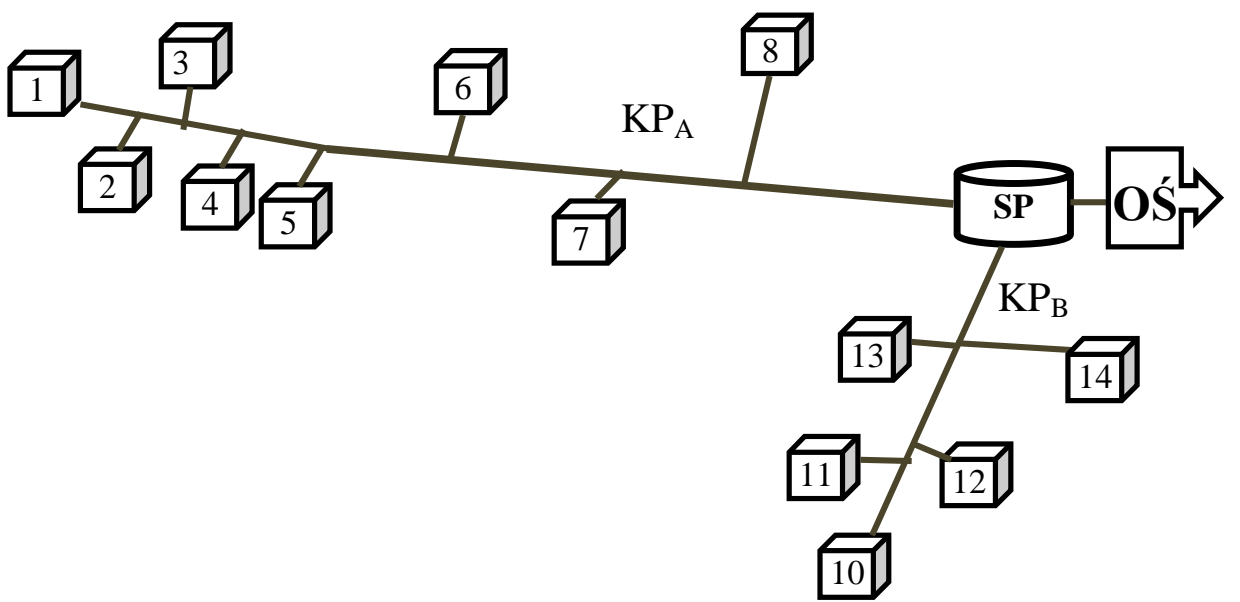

Rys.1. Schemat przykładowego systemu kanalizacji podciśnieniowej

Fig.1. The schema of example a vacuum sewer system

Tabela 5. Charakterystyki elementów przykładowego systemu kanalizacji podciśnieniowej

Table 5. A vacuum sewer system - characteristics of elements

\begin{tabular}{|c|c|c|c|c|c|c|c|c|c|}
\hline \multirow{2}{*}{ Opis } & \multicolumn{9}{|c|}{ Gałąź A } \\
\hline & \multicolumn{8}{|c|}{ Obiekty domowe podłączone do $\mathbf{K P}_{\mathrm{A}}$} & $\mathbf{K} \mathbf{P}_{\mathbf{A}}$ \\
\hline Elem. i & 1 & 2 & 3 & \begin{tabular}{l|l}
4 & \\
\end{tabular} & \begin{tabular}{l|l}
5 & \\
\end{tabular} & 6 & 7 & 8 & 9 \\
\hline Qi [\%Qn] & 8 & 8 & 13 & 7 & 7 & 7 & 10 & 10 & 70 \\
\hline $\mathrm{Ki}$ & 0,9 & 0,9 & 0,87 & 0,9 & 0,9 & 0,9 & 0,89 & 0,89 & 0,92 \\
\hline \multirow{2}{*}{ Opis } & \multicolumn{7}{|c|}{ Gałąź B } & \multirow{2}{*}{\multicolumn{2}{|c|}{ SP }} \\
\hline & \multicolumn{5}{|c|}{ Obiekty podłączone do $\mathrm{KP}_{\mathrm{B}}$} & & $\mathbf{K} \mathbf{P}_{\mathbf{B}}$ & & \\
\hline Elem. i & 10 & 11 & 12 & 13 & \multicolumn{2}{|l|}{14} & 15 & \multicolumn{2}{|c|}{16} \\
\hline Qi [\%Qn] & 5 & 7 & 9 & 3 & \multicolumn{2}{|l|}{6} & 30 & \multicolumn{2}{|c|}{100} \\
\hline $\mathrm{Ki}$ & 0,91 & 0,9 & 0,89 & 0,93 & 0,91 & & 0,93 & \multicolumn{2}{|c|}{0,96} \\
\hline
\end{tabular}

W tym systemie są następujące trzy obiekty krytyczne:

- stacja próżniowa SP - jej niesprawność powoduje niedobór o wielkości $\mathrm{N}(\mathrm{SP})=100 \% \mathrm{Qn}$,

- kolektor $\mathrm{KP}_{\mathrm{A}}$ - jego niesprawność powoduje niedobór o wielkości $\mathrm{N}\left(\mathrm{KP}_{\mathrm{A}}\right)=70 \%$ Qn (co stanowi 100\% jego nominalnej wydajności),

- kolektor $\mathrm{KP}_{\mathrm{B}}$ - jego niesprawność powoduje niedobór o wielkości $\mathrm{N}\left(\mathrm{KP}_{\mathrm{B}}\right)=30 \%$ Qn (co stanowi 100\% jego nominalnej wydajności).

Pozostałe elementy nie są krytyczne. Wyznaczanie EN(SKP) należy prowadzić etapami: 
1. wyznaczenie średniego niedoboru dla gałęzi A, której elementem krytycznym jest $\mathrm{KP}_{\mathrm{A}}$,

2. wyznaczenie średniego niedoboru dla gałęzi $B$, której elementem krytycznym jest $\mathrm{KP}_{\mathrm{B}}$,

3. wyznaczenie średniego niedoboru dla systemu, w którym elementem krytycznym jest SP.

Poniżej obszerniej przedstawiono w/w etapy.

Etap 1. Średni niedobór skumulowany dla obiektów domowych (elementów zwykłych) wyznacza się zgodnie $\mathrm{z}$ wzorem (10) jako sumę ENs(A) $=2 \cdot 8 \%$ Qn $\cdot 0,1+13 \%$ Qn $\cdot 0,13+3 \cdot 7 \%$ Qn $\cdot 0,1+2 \cdot 10 \%$ Qn $\cdot 0,11=7,59 \%$ Qn. Zgodnie z (10) jest to suma niedoborów grup jednorodnych elementów. Średni niedobór dla całej gałęzi A, zawierającej oprócz elementu zwykłego jeden element krytyczny, wyznacza się zgodnie z (11) jako średnią ważoną.

$\mathrm{EN}(\mathrm{A})=\mathrm{ENs}(\mathrm{A}) \cdot \mathrm{K} 9+\mathrm{Q} 9 \cdot(1-\mathrm{K} 9)=7,59 \% \mathrm{Qn} \cdot 0,92+70 \% \mathrm{Qn} \cdot 0,08 \mathrm{Uz}$ yskujemy wartość $\mathrm{EN}(\mathrm{A})=12,5828 \%$ Qn.

Etap 2. Średni niedobór skumulowany dla obiektów domowych wyznacza się zgodnie $\mathrm{z}$ (4) jako sumę niedoborów elementów $\mathrm{ENs}(\mathrm{B})=5 \cdot 0,09+7 \cdot 0,1+9 \cdot 0,11+3 \cdot 0,07+6 \cdot 0,09+30 \cdot 0,07=2,89 \%$ QnŚredni niedobór dla całej gałęzi B wyznacza się zgodnie z (11) jako średnią ważoną $\mathrm{EN}(\mathrm{B})=\mathrm{ENs}(\mathrm{B}) \cdot \mathrm{K} 15+\mathrm{Q} 15 \cdot(1-\mathrm{K} 15)=. \quad 2,89 \cdot 0,93+30 \cdot 0,07$ Uzyskujemy wartość $\mathrm{EN}(\mathrm{B})=4,7877 \%$ Qn.

Etap 3. Średni niedobór dla całego systemu wyznaczamy zgodnie z (11) jako $\mathrm{EN}(\mathrm{S})=\mathrm{EN}(\mathrm{A}+\mathrm{B}) \cdot \mathrm{K} 16+\mathrm{Q} 16 \cdot(1-\mathrm{K} 16)$. Średni niedobór obu gałęzi wyznaczamy jako sumę niedoborów niezależnie działających gałęzi A i B, które na tym etapie należy traktować jako elementy zwykłe. Stąd $\mathrm{EN}(\mathrm{A}+\mathrm{B})=\mathrm{EN}(\mathrm{A})+\mathrm{EN}(\mathrm{B})$. W rezultacie uzyskujemy dokładną wartość niedoboru przykładowego systemu kanalizacji podciśnieniowej $\mathrm{EN}(\mathrm{SKP})=$ $20,67568 \%$ Qn.

Uzyskany wynik poddano weryfikacji za pomoca MPZ. Za pomocą makra utworzonego w EXCEL-u wygenerowano I(MPZ) $=2^{16}=65536$ stanów elementarnych systemu. Uzyskano wynik EN(MPZ) $=20,6757 \%$ Qn. Jak wiadomo pracochłonność dokładnej MPZ jest bardzo duża.

Nawet posiadając uniwersalny program generujący wszystkie stany elementarne systemu, do wyznaczenia EN konieczne jest uwzględnienie struktury systemu, co jest realizowane za pomocą odpowiednich formuł (czasem megaformuł) do wyznaczania niedoborów dla wszystkich stanów elementarnych systemu.

Nieporównywalnie łatwiej i szybciej można wyznaczyć EN(SKP) za pomocą MKN. Nawet znaczna liczba elementów systemu nie zwiększa w istotny sposób pracochłonności metody, a obliczenia można przeprowadzić za pomocą kalkulatora. Prowadzenie obliczeń jest intuicyjnie proste, gdyż de facto opiera się na wykorzystaniu wzoru na prawdopodobieństwo zupełne. 


\section{Metoda dla kanalizacji grawitacyjnej}

Idea MKN zostanie przedstawiona na prostym przykładzie. System kanalizacji grawitacyjnej (SKG) składa się z n=5 elementów (rys.2). Dla każdego i-tego elementu (kanału) znana jego niezawodność Ki oraz maksymalna wielkość dopływu Qi z części zlewni przynależnej do i-tego odcinka kanalizacji.

Na podstawie znajomości struktury systemu, dla każdego elementu wyznacza się całkowitą ilość ścieków przepływających przez dany element Qci (tab.5). W dalszej części przyjęto, że uszkodzenia kanałów następują w dolnych ich węzłach.

W przypadku kanalizacji grawitacyjnej niemożliwe jest zbyt duże uproszczenie metody. Ze względu na specyfikę działania kanalizacji grawitacyjnej, praktycznie na każdym kroku należy uwzględniać hierarchię elementów.

Tutaj dla wszystkich elementów podrzędnych znajdujących się na jednym poziomie hierarchii (np. elementy 1 i 2) można zastosować wzór (3) lub (9).

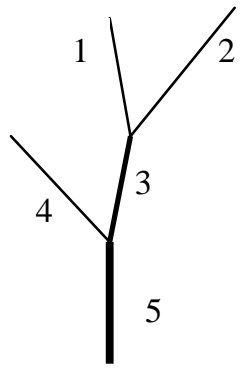

Rys.2. Prosty system kanalizacji grawitacyjnej

Fig.2. A simple gravity sewer system

Tabela 6. Charakterystyki elementów prostego systemu kanalizacji grawitacyjnej

Table 6. A simple gravity sewer system - characteristics of elements

\begin{tabular}{|c|c|c|c|c|c|}
\hline \multirow{2}{*}{$\begin{array}{c}\text { Parametry i-tego } \\
\text { elementu }\end{array}$} & \multicolumn{5}{|c|}{ Numer elementu i } \\
\cline { 2 - 6 } & $\mathbf{1}$ & $\mathbf{2}$ & $\mathbf{3}$ & $\mathbf{4}$ & $\mathbf{5}$ \\
\hline Qi [\%Qn] & 5 & 10 & 15 & 20 & 50 \\
\hline Qci [\%Qn] & 5 & 10 & 30 & 20 & 100 \\
\hline Ki & 0,95 & 0,9 & 0,94 & 0,9 & 0,92 \\
\hline
\end{tabular}

Natomiast dla elementu nadrzędnego odbierającego ścieki z elementów podrzędnych (np. element 3) średni niedobór skumulowany można wyrazić jak średni niedobór skumulowany dla elementu krytycznego w kanalizacji podciśnieniowej (11). Idąc dalej: element 3, który na początku był elementem nadrzędnym dla elementów 1 i 2, w kolejnym kroku jest traktowany tak samo jak element 4 (tzn. elementy 3 i 4 są podrzędne w stosunku do elementu 5). Stąd kolejno mamy: 


$$
\begin{aligned}
& \mathrm{ENs}(2)=\mathrm{EN} 1+\mathrm{EN} 2=1,25 \% \text { Qn } \\
& \mathrm{ENs}(3)=\mathrm{ENs}(2) \cdot \mathrm{K} 3+\mathrm{N} 3 \cdot(1-\mathrm{K} 3)=2,975 \% \text { Qn } \\
& \mathrm{ENs}(4)=\mathrm{ENs}(3) \cdot \mathrm{K} 4+(\mathrm{N} 4+\mathrm{ENs}(3)) \cdot(1-\mathrm{K} 4)=4,975 \% \text { Qn } \\
& \mathrm{ENs}(5)=\mathrm{ENs}(4) \cdot \mathrm{K} 5+100 \cdot(1-\mathrm{K} 5)=12,577 \% \text { Qn }
\end{aligned}
$$

Obliczenia za pomocą MKN dla systemów kanalizacji grawitacyjnej można również prowadzić tabelarycznie (tab.7). W tej tabeli dla ułatwienia można uwzględnić dodatkową kolumnę jak w tabelach 3 i 4.

Dokładnie taki sam wynik uzyskujemy stosując MPZ (tab.8) i wyznaczając:

$$
\mathrm{EN}(\mathrm{S})=\sum_{\mathrm{z}=1}^{32} \mathrm{Nz} \cdot \mathrm{Pz}
$$

\begin{tabular}{|c|c|c|c|c|}
\hline \multicolumn{2}{|c|}{ Element } & \multirow{2}{*}{$\begin{array}{l}\text { Niedobór wy- } \\
\text { nikający ze } \\
\text { stanu elementu } \\
\text { [\% Qn] }\end{array}$} & \multirow{2}{*}{$\begin{array}{l}\text { Prawdopodo- } \\
\text { bieństwo } \\
\text { stanu }\end{array}$} & \multirow{2}{*}{$\begin{array}{l}\text { Średni niedobór skumulowany } \\
\text { ENs(i) [\% Qn] }\end{array}$} \\
\hline $\mathbf{i}$ & stan & & & \\
\hline \multirow{2}{*}{1} & + & 0 & $\mathrm{~K} 1=0,95$ & \multirow{2}{*}{$\mathrm{ENs}(1)=\mathrm{N} 1 \cdot(1-\mathrm{K} 1)=0,25$} \\
\hline & - & $\mathrm{N} 1=\mathrm{Qc} 1=5$ & $1-\mathrm{K} 1=0,05$ & \\
\hline \multirow{2}{*}{2} & + & 0 & $\mathrm{~K} 2=0,9$ & \multirow{2}{*}{$\begin{array}{l}\mathrm{ENs}(2)=\mathrm{ENs}(1) \cdot \mathrm{K} 2+ \\
{[\mathrm{N} 2+\mathrm{ENs}(1)](1-\mathrm{K} 2)=1,25}\end{array}$} \\
\hline & - & $\mathrm{N} 2=\mathrm{Qc} 2=10$ & $1-\mathrm{K} 2=0,1$ & \\
\hline \multirow{2}{*}{3} & + & 0 & $\mathrm{~K} 3=0,94$ & \multirow{2}{*}{$\begin{array}{l}\mathrm{ENs}(3)=\mathrm{ENs}(2) \cdot \mathrm{K} 3+ \\
+\mathrm{N} 3 \cdot(1-\mathrm{K} 3)=2,975\end{array}$} \\
\hline & - & $\mathrm{N} 3=\mathrm{Qc} 3=30$ & $1-\mathrm{K} 3=0,06$ & \\
\hline \multirow{2}{*}{4} & + & 0 & $\mathrm{~K} 4=0,9$ & \multirow{2}{*}{$\begin{array}{l}\mathrm{ENs}(4)=\mathrm{ENs}(3) \cdot \mathrm{K} 4+[\mathrm{N} 4+\mathrm{ENs}(3)] \\
\cdot(1-\mathrm{K} 4)=4,975\end{array}$} \\
\hline & - & $\mathrm{N} 4=\mathrm{Qc} 4=20$ & $1-\mathrm{K} 4=0,1$ & \\
\hline \multirow{2}{*}{5} & + & 0 & $\mathrm{~K} 5=0,92$ & \multirow{2}{*}{$\begin{array}{l}\mathrm{ENs}(5)=\mathrm{ENs}(4) \cdot \mathrm{K} 5+ \\
+\mathrm{N} 5 \cdot(1-\mathrm{K} 5)=12,577\end{array}$} \\
\hline & - & $\mathrm{N} 5=\mathrm{Qc} 5=100$ & $1-\mathrm{K} 5=0,08$ & \\
\hline
\end{tabular}

gdzie $\mathrm{z}$ - numer stanu elementarnego systemu, Nz - niedobór występujący w z-tym stanie, $\mathrm{Pz}$ - prawdopodobieństwo zajścia z-tego stanu SKP.

Tabela 7. Prowadzenie obliczeń dla SKG za pomocą metody kumulacji niedoborów

Table 7. Calculation of SKG using the deficit accumulation method

Można zauważyć, że dla SKG złożonego tylko z n=5 elementów różnica w pracochłonności metod jest już duża. W MPZ liczba stanów $I(M P Z)=2^{n}$ rośnie wykładniczo, natomiast w MKN liczba wierszy wynosi jedynie 2.n. Obliczenia w MKN łatwo też zaprogramować. 
Tabela 8. Zastosowanie MPZ do wyznaczania średniego niedoboru dla przykładowego systemu kanalizacji grawitacyjnej

Table 8. Application of MPZ to determine the average deficit in a gravity sewer system

\begin{tabular}{|c|c|c|c|c|c|c|c|c|c|}
\hline \multirow{2}{*}{$\begin{array}{c}\text { Stan } \\
\mathbf{z}\end{array}$} & \multirow{2}{*}{$\mathbf{k}$} & \multicolumn{5}{|c|}{ Elementy } & \multirow{2}{*}{$\mathbf{P z}$} & \multirow{2}{*}{$\mathrm{Nz}[\% \mathbf{Q n}]$} & \multirow{2}{*}{$\mathbf{N z} \cdot \mathbf{P z}$} \\
\hline & & 1 & 2 & 3 & 4 & 5 & & & \\
\hline 1 & 0 & 1 & 1 & 1 & 1 & 1 & 0,66546 & 0 & 0 \\
\hline 2 & 1 & 0 & 1 & 1 & 1 & 1 & 0,03502 & 5 & 0,175122 \\
\hline 3 & 1 & 1 & 0 & 1 & 1 & 1 & 0,07394 & 10 & 0,739404 \\
\hline 4 & 2 & 0 & 0 & 1 & 1 & 1 & 0,00389 & 15 & 0,058374 \\
\hline 5 & 1 & 1 & 1 & 0 & 1 & 1 & 0,04248 & 30 & 1,274292 \\
\hline 6 & 2 & 0 & 1 & 0 & 1 & 1 & 0,00224 & 30 & 0,067068 \\
\hline 7 & 2 & 1 & 0 & 0 & 1 & 1 & 0,00472 & 30 & 0,141588 \\
\hline 8 & 3 & 0 & 0 & 0 & 1 & 1 & 0,00025 & 30 & 0,007452 \\
\hline 9 & 1 & 1 & 1 & 1 & 0 & 1 & 0,07394 & 20 & 1,478808 \\
\hline 10 & 2 & 0 & 1 & 1 & 0 & 1 & 0,00389 & 25 & 0,09729 \\
\hline 11 & 2 & 1 & 0 & 1 & 0 & 1 & 0,00822 & 30 & 0,246468 \\
\hline 12 & 3 & 0 & 0 & 1 & 0 & 1 & 0,00043 & 35 & 0,015134 \\
\hline 13 & 2 & 1 & 1 & 0 & 0 & 1 & 0,00472 & 50 & 0,23598 \\
\hline 14 & 3 & 0 & 1 & 0 & 0 & 1 & 0,00025 & 50 & 0,01242 \\
\hline 15 & 3 & 1 & 0 & 0 & 0 & 1 & 0,00052 & 50 & 0,02622 \\
\hline 16 & 4 & 0 & 0 & 0 & 0 & 1 & $2,8 \mathrm{E}-05$ & 50 & 0,00138 \\
\hline 17 & 1 & 1 & 1 & 1 & 1 & 0 & 0,05787 & 100 & 5,78664 \\
\hline 18 & 2 & 0 & 1 & 1 & 1 & 0 & 0,00305 & 100 & 0,30456 \\
\hline 19 & 2 & 1 & 0 & 1 & 1 & 0 & 0,00643 & 100 & 0,64296 \\
\hline 20 & 3 & 0 & 0 & 1 & 1 & 0 & 0,00034 & 100 & 0,03384 \\
\hline 21 & 2 & 1 & 1 & 0 & 1 & 0 & 0,00369 & 100 & 0,36936 \\
\hline 22 & 3 & 0 & 1 & 0 & 1 & 0 & 0,00019 & 100 & 0,01944 \\
\hline 23 & 3 & 1 & 0 & 0 & 1 & 0 & 0,00041 & 100 & 0,04104 \\
\hline 24 & 4 & 0 & 0 & 0 & 1 & 0 & $2,2 \mathrm{E}-05$ & 100 & 0,00216 \\
\hline 25 & 2 & 1 & 1 & 1 & 0 & 0 & 0,00643 & 100 & 0,64296 \\
\hline 26 & 3 & 0 & 1 & 1 & 0 & 0 & 0,00034 & 100 & 0,03384 \\
\hline 27 & 3 & 1 & 0 & 1 & 0 & 0 & 0,00071 & 100 & 0,07144 \\
\hline 28 & 4 & 0 & 0 & 1 & 0 & 0 & $3,8 \mathrm{E}-05$ & 100 & 0,00376 \\
\hline 29 & 3 & 1 & 1 & 0 & 0 & 0 & 0,00041 & 100 & 0,04104 \\
\hline 30 & 4 & 0 & 1 & 0 & 0 & 0 & $2,2 \mathrm{E}-05$ & 100 & 0,00216 \\
\hline 31 & 4 & 1 & 0 & 0 & 0 & 0 & $4,6 \mathrm{E}-05$ & 100 & 0,00456 \\
\hline 32 & 5 & 0 & 0 & 0 & 0 & 0 & $2,4 \mathrm{E}-06$ & 100 & 0,00024 \\
\hline & & & & & & & & Razem & 12,577 \\
\hline
\end{tabular}




\section{Uwagi}

Badania niezawodności systemów kanalizacyjnych zostały zapoczątkowane znacznie później niż analogiczne badania sieci wodociągowych, gazowniczych czy ciepłowniczych. Dlatego stan tych badań nie jest zadowalający. Dotychczas przeprowadzano głównie badania eksploatacyjne obiektów kanalizacyjnych i szacowano wartości podstawowych miar niezawodności tych systemów. Według ocen wielu badaczy, zarówno w literaturze krajowej jak i zagranicznej jest bardzo niewiele wyników badań dotyczących miar niezawodności i metod ich wyznaczania dla systemów kanalizacyjnych. Ten obszar badań jest na etapie rozwoju, nadal poszukuje się najbardziej odpowiednich metod wyznaczania miar niezawodności dla systemów kanalizacyjnych [7].

Dotychczas średnią ilość ścieków EN nieodprowadzonych z danego obszaru przez system kanalizacyjny (grawitacyjny lub podciśnieniowy) wyznaczano najczęściej za pomocą metody przeglądu częściowego. Oprócz wypisania wszystkich uwzględnianych stanów systemu konieczne było uwzględnienie struktury systemu, czyli określenie reguł do wyznaczania niedoborów w tych stanach. Rezultatem pracochłonnych działań był wynik przybliżony, przy czym na ogół nie szacowano możliwego błędu metody, wierząc że jest on mały $[1,2,3]$.

Przedstawiona metoda kumulacji niedoborów jest zarazem prosta i dokładna. Opracowanie jej związane było i innym niż dotychczas podejściem do wyznaczania średniego niedoboru systemu. Metoda nie opiera się bowiem na metodzie przeglądu, która w każdym uwzględnianym stanie elementarnym systemu uwzględnia wszystkie istotne elementy systemu. W nowej metodzie do dokładnego wyniku EN(S) dochodzi się uwzględniając na poszczególnych etapach kolejne elementy systemu, przy równoczesnym hierarchicznym odwzorowaniu drzewiastej struktury systemu za pomocą odpowiednich wzorów. Wzory są proste i intuicyjnie zrozumiałe, a ich słuszność została wykazana. Wynikają one bowiem z procesu dekompozycji SK i zastosowania wzoru na prawdopodobieństwo zupełne. Metoda z powodzeniem może być stosowana dla dużych systemów kanalizacji podciśnieniowej, grawitacyjnej i mieszanej.

\section{Wnioski}

- Systemy kanalizacyjne funkcjonujące w różnych jednostkach osadniczych z uwagi na ukształtowanie terenu, rodzaj kanalizacji, liczbę osób korzystających z kanalizacji czy rozległość mogą być odmienne. Jednak systemy kanalizacji grawitacyjnej i podciśnieniowej można odwzorować w podobny sposób za pomocą struktury drzewiastej.

- Praktyczną miarą niezawodności SK jest średnia ilość nieodprowadzonych ścieków EN.

- Nowa, oryginalna metoda kumulacji niedoborów (MKN) pozwala na wyznaczenie dokładnej (dla przyjętej struktury) wartości EN. 
- Wiarygodność wyniku EN zależy od stopnia uproszczenia struktury czyli od uwzględnienia lub pominięcia istotnych elementów SK (kanałów, kolektorów, przepompowni ścieków) oraz od przyjęcia realnych danych (niezawodności uwzględnianych elementów oraz ilości odprowadzanych/przepływających przez nie ścieków).

- MKN pozwala na uwzględnienie w modelu dowolnie dużej liczby elementów systemu przy niewielkim nakładzie pracy. Liczba koniecznych obliczeń wraz ze wzrostem liczby elementów systemu w MKN wzrasta liniowo, natomiast w MPZ wrasta wykładniczo.

- Obliczenia w MKN można przeprowadzać przy użyciu najprostszego kalkulatora, lub nawet ręcznie.

- MKN można stosować dla systemów kanalizacji grawitacyjnej, podciśnieniowej i mieszanej.

\section{Literatura}

[1] Iwanejko R., Accuracy of reliability measures of water supply and sewage facilities. Scientific problems of machines operation and maintenance. Polish Academy of Sciences. 1(157) vol.44, 2009.

[2] Iwanejko R., Bajer J., Rozważania o wybranych metodach wyznaczania niezawodności systemu kanalizacji grawitacyjnej, Czasopismo Inżynierii Lądowej, Środowiska i Architektury, JCEEA, t. XXXII, z. 62 (1/15) 2015,s.109-124.

[3] Iwanejko R., Bajer J., Rozważania o wybranych metodach wyznaczania niezawodności systemu kanalizacji podciśnieniowej, Czasopismo Inżynierii Lądowej, Środowiska i Architektury, JCEEA, t. XXXII, z. 62 (1/15) 2015,s.125-136.

[4] Królikowska J., Niezawodność funkcjonowania i bezpieczeństwa sieci kanalizacyjnej. Wydawnictwo Politechniki Krakowskiej, Monografia 382. Seria Inżynieria Środowiska. Kraków, 2010.

[5] Królikowska J., Przegląd metod do oceny niezawodności działania sieci kanalizacyjnej. Materiały konferencji Naukowo-Technicznej „AQUA”, Szczyrk 2013.

[6] Kwietniewski M., Roman M., Kłoss-Trębaczkiewicz H., Niezawodność wodociągów i kanalizacji. Arkady, Warszawa, 1993.

[7] Kwietniewski M., Rak J., Niezawodność infrastruktury wodociągowej i kanalizacyjnej w Polsce. Polska Akademia Nauk. Komitet Inżynierii Lądowej i Wodnej. Instytut Podstawowych problemów Techniki. Warszawa 2010.

[8] Wieczysty A., Lubowiecka T., Niezawodność systemów zaopatrzenia miasta w wodę. Materiały XIV Seminarium projektantów wodociągów. Wydawnictwo PZiTS O/Kraków, zakopane, 1984, s.12-25.

[9] Wieczysty A., Niezawodność systemów wodociągowych i kanalizacyjnych. Wydawnictwo Politechniki Krakowskiej. Kraków, 1990. 


\section{NEW ANALYTICAL METHOD TO DETERMINE THE AVERAGE AMOUNT OF WASTEWATER NOT DISCHARGED TO VACUUM AND GRAVITY SEWAGE SYSTEM}

\section{S u m m a r y}

The sewage system is design to collect a certain amount of wastewater from the particular site. Therefore, sewage systems, as a part of a critical urban infrastructure, should show high operation reliability. Their failures results in wastewater spills and contamination of both ground surface and soil, groundwater pollution, flooding underground urban infrastructures and building foundations as well as other sewage disasters. Sewer systems failures affect not only the residents of the serviced areas but primarily the natural environment. Contemporary sewage systems consist of elements and objects that have been in operation for many decades, and hence their technical conditions may be unsatisfactory. Therefore, failures of the sewage system are quite common. The average amount of sewage that is not discharged to the sewer system (EN) is a convenient basic indicator describing the sewer system reliability. The methods for EN determination currently known and used are not satisfactory. They are time consuming and difficult in practical applications, and once simplified do not evaluate the method's error. The paper presents an original new method of deficit cumulation (MKN). The method allows to specify the expected amount of sewage that have not been discharged from the site. The method is straightforward, easy to understand, accurate and time saving though involves an unusual approach to determine the average water deficit. The method can be used for gravity, vacuum and mixed sewer systems and it does not limit a number of sewer system elements.

Keywords: reliability, failure, sewer system, wastewater

Przestano do redakcji: 30.05 .2015 r.

Przyjęto do druku: 30.10 .2015 r.

DOI: $10.7862 / \mathrm{rb} .2015 .102$ 